\title{
Adaptive Reuse of Architectural Heritage and Its Role in the Post-Disaster Reconstruction of Urban Identity: Post-Communist Łódź
}

\author{
Julia Sowińska-Heim $(\mathbb{D}$ \\ Department of History of Architecture, Institute of History of Art, Faculty of Philosophy and History, \\ University of Lodz, 90-136 Łódź, Poland; julia.sowinska@uni.lodz.pl
}

Received: 31 August 2020; Accepted: 25 September 2020; Published: 29 September 2020

check for updates

\begin{abstract}
The article examines the role of the adaptive reuse of architectural heritage in urban identity reconstruction and strengthening undertaken after the disaster caused by a strong economic and social crisis. The main research material includes activities and projects implemented in post-communist Łódź, one of the largest Polish cities. The city developed extremely dynamically at the beginning of the 19th century as a centre of textile industry. Characteristic factories located in the city centre operated continuously until the end of the 1980s, when the transformation brought about radical political changes, as a result of which Łódź experienced a rapid process of deindustrialisation. The nineteenth-century architectural heritage played an important role in the search for ways to regenerate the city and redefine its identity. Starting from the local, i.e., historical, social or identity contexts, the reader is led to universal conclusions, concerning important problems, issues and challenges related to the confrontation of architectural heritage with contemporary needs and expectations.
\end{abstract}

Keywords: architectural heritage; adaptive reuse; protection of cultural heritage; cultural heritage; post-industrial heritage; Łódź; disaster

\section{Introduction}

Disaster is a sudden and tragic event, which results in extensive and negative effects that sometimes entail the need to reconstruct a city or its important areas; it is primarily associated with a war or a natural disaster. However, as the example of Łódź shows, economic and socio-political changes may sometimes have such an extensive scale, with such sudden and far-reaching consequences, that for the city and its inhabitants this can become a true catastrophe. At the same time, the modern history of Łódź serves as a proof that architectural heritage may play an important, if not crucial role in the post-disaster reconstruction of a city and its identity after such a misfortune.

Significant architectural and historical monuments become an important point of reference for the local population, increasing their sense of security, and act as an important factor shaping social identity. An effort to preserve relevant objects in a city is therefore important both for retaining its unique features - which, according to René Dubos, can be described as the city's "structure of personality" [1] - and for strengthening the local community.

At the same time, "a post-disaster reconstruction", as clearly demonstrated by the history of Łódź, can be a special stimulus leading to the rediscovery, redefinition and reinterpretation of both the urban space and architectural heritage. Such processes are becoming one of the essential tools legitimising the new order, as well as an instrument for establishing urban identity in new economic, social, political and cultural environments. As a result, artefacts of the past gain new meanings, which are subject to a different, contemporary interpretation through the prism of current needs and 
ideas. Objects or even groups of objects from the past are being consciously taken into consideration in the activities currently undertaken by the city's authorities.

In Łódź, large-scale adaptive reuse played a crucial role in the process of urban reconstruction. A number of possible transformations resulting from a functional change that meets the contemporary needs makes adaptive reuse play an important role in the process of reviving and regenerating degraded areas. This allows for the preservation of architectural objects that are important to the local community, promoting the integrity and historical continuity of the city while restoring the objects' functional and economic value. These processes play a particularly important role in post-industrial cities, such as Łódź, where the economic changes and steep decline of traditional industries caused significant areas to be deprived of their original purpose, resulting in a rapid deterioration.

The introduction of a new function in post-industrial facilities is not only an important impulse for the previously mentioned tangible regeneration of urban tissue, but can also help to reconstruct the image and identity of a city. The local cultural and architectural heritage plays a significant role in the process leading to the creation of positive references and elimination of negative connotations related to an economic or social crisis. These remain an important part of the history of a city and, at the same time, its significance may be reimagined and shown in a new context, that relates to the present day.

\section{Adaptive Reuse-Key Assumptions, Documents and Publications}

In the late 20th century and at the beginning of the 21st century, the opinion that cultural heritage should not be seen as constant and static, but instead needs to be constantly redefined to reflect human activity, was gaining popularity in the documents concerning cultural heritage [2,3] (art. 2 and Preamble). An important role was played by the emphasis on the complex social values of heritage, visible since the 1970s [4-7]. This aspect is linked to the clearly visible increase in the importance of intangible heritage assets, which are strongly interlinked with social and cultural factors, and the belief that they need to be taken into account on a par with the material value of a property [7-9].

The assumption that conservation aims not only at the protection of material values, but also at the preservation of the cultural meaning of a place important for both past, present and future generations [7] (Preamble), is connected with the observation that these values are not universal/absolute, since the value of a place may be different for different groups and individuals [7] (art. 1.2). What is more, the cultural meaning may change as a result of acquiring new information, as well as during the continuous formation of the history of the place [7] (art. 1.2 with Explanatory notes). Conservation should therefore not only concern the material substance and methods of use, but also the meanings (for example symbolic ones and related to memories) and links understood as social, spiritual and cultural relationships between the people and the place [7] (art. 1.15, 1.16, 3.1). Accentuating the social meaning of heritage and adopting a value-based approach has shifted the emphasis from the universal values belonging to the site, which can be revealed through a proper investigation carried out by a small group of experts, to values that are important for the development and quality of human life [2] (pt. c). There is thus a shift from a traditional approach, which sees values as fixed and unchangeable, inherently associated to the site, to values that result from the interaction between the site and the historical, social or spatial context associated with it. In fact, in 2005, the Convention on the Value of Cultural Heritage for Society, known as the Faro Convention, recognised the need for the whole society to participate in a continuous process of defining cultural heritage [2] (Preamble). This highlights the diverse and variable possibilities of perception and interpretation, which are not subject to clear and set definitions. Cultural heritage itself was defined as a collection of resources from the past that are being approached by people as a form of reflection and expression of their constantly evolving values, beliefs, knowledge and traditions [2] (art. 15). This significant change in perspective and way of thinking led to the conclusion that the primary goal of protecting cultural heritage is human development and improvements in quality of life [2] (art. 1, pt. c). In contrast, just over forty years earlier, in the Venice Charter- that was adopted in 1964, and was a fundamental document for the 
theory of heritage conservation in the 20th century-the importance of protection and conservation of works of art was understood only as the preservation of the material form and substance [10].

Shifting the emphasis from the importance of the material values of a building, without negating them, to the values related to an individual (a recipient and user), their perception of the cultural heritage, as well as established associations and relationships must be accompanied by a fundamental modification of the way of thinking, taking a broader view of architectural heritage protection and including factors such as cultural, social and economic changes in the analysis [11,12]. Each time the local context and cultural meaning of the historical building must be taken into account $[13,14]$.

At the same time, the preservation of the architectural heritage (structure of historical centres and places) and its integration within contemporary social life [6] (pt. 7) foster a harmonious social balance and the formation of a complete (holistic) and sustainable living environment [4] (pt. 1.4). As the Declaration of Amsterdam emphasised in the mid-1970s, "historical continuity must be preserved in the environment if we are to maintain or create surroundings which enable individuals to find their identity and feel secure despite abrupt social changes" [5].

Recognising heritage as not only a testimony of the past but also of cultural, social and economic capital [15] leads to a special interaction and dialogue between history and the present. In this context, the introduction of a new contemporary function for architectural heritage plays an important role. In recent years, there has been a clear increase in interest about adaptive reuse, which is starting to emerge as a new, independent scientific discipline [16]. In scientific literature, it is discussed mainly in publications devoted to the protection of cultural assets and approached as a domain relating to the restoration of monuments, or analysed through the prism of strictly architectural issues, and therefore focusing mainly on attempts to identify design methods that could be used to build relations between the original structure and its contemporary transformation [9,16-18]. The novel concept is research on the "vernacular adaptation" of built heritage and its role as a catalyst in the transformation of the formal adaptive practice [19]. There are also attempts to create a model for developing adaptive reuse strategies for architectural heritage [20], as well as a holistic view of the phenomenon of adaptive reuse as a consequence of social changes and changes in the understanding of heritage and its protection [12].

In heritage conservation practice, adaptation does not necessarily mean the functional change of a building. The Burra Charter clearly states that adaptation means changing a place to suit the existing use or a proposed use [8] (art. 1.9; 1.10). At the same time, it is mentioned that such changes should only be allowed if they have limited impact on the cultural significance of the place. The fundamental document that formulates recommendations is the Venice Charter (1964), which, although not focusing on the adaptation process itself, does state that the purpose (use) of the architectural monuments "for some socially useful purpose" [10] (art. 5) promotes their conservation and is therefore desirable, provided that it does not entail changes in the layout and design of the building. An interesting point of view in the context of the issues discussed above can be found in the Recommendation concerning the Safeguarding and Contemporary Role of Historic Areas, from 1976 (Warsaw-Nairobi) [6]. This document points out that the fundamental elements of town planning and land development are both the protection of historic areas and their integration into modern social life. Such areas should be approached from the perspectives of both an important historical and social testimony and the daily environment, and that gives them an additional "humanistic dimension". Similar ideas are also mentioned in later documents, and their interpretation is slightly more comprehensive. For example, the 1985 Convention for the Protection of the Architectural Heritage of Europe declared support for the use of protected properties in light of the new uses and, where possible, for the adaptation of "old buildings to new uses" [21] (art. 11), provided that access to cultural objects should not affect their architectural or historical nature, whether in terms of the object itself or the environment in which it is located. The 1987 ICOMOS Charter for the Conservation of Historic Towns and Urban Areas (known as the Washington Charter), which refers to the 1976 Recommendation and other international documents, underlines that the protection of historical towns and areas entails the application of the measures necessary for their "protection, conservation and restoration" and "their development and harmonious 
adaptation to contemporary life" [22] (Preamble and definitions). There is a provision in this Charter which states that the introduction of "elements of contemporary character" into an object may possibly enrich it, provided that these do not interfere with "the integrity of its structural harmony".

These assumptions were later confirmed in the 2011 Valletta Principles for the Safeguarding and Management of Historic Cities, Towns and Urban Areas [23]. However, the document recognises functional changes as a significant threat. Interestingly, these are seen as relating mainly to changes concerning intangible assets, and not to potential interventions in the material architectural tissue. The outflow of the indigenous community might result in the disappearance of local traditions and customs, leading to the erosion of the original character of a place and, possibly, its identity (2.c). The social aspect is being strongly and evidently emphasised, as well as the need to counteract processes such as gentrification and the reduction of historical districts to tourist attractions deprived of normal, everyday life. These documents clearly show a perception of the architectural heritage not only as a protected artefact of the past, a historical testimony, but also an important element of contemporary social life.

In adaptive reuse, as highlighted in the 2010 Charter for Conservation of Places of Cultural Heritage Value (among others), the new function should be compatible with the original [24]. According to the authors of the document, this means that it should be compatible with the cultural values of a place, so that its authenticity and integrity are not adversely affected. It is also emphasised that although adaptive reuse might result in interference with the architectural tissue, for example reconstruction and extensions, these should not dominate the original form and structure. Therefore, the inappropriate juxtaposition of forms, scale, colours or materials should be avoided. The abovementioned documents define and broaden the approach of the Venice Charter to adaption, putting the emphasis on cultural and social values, although de facto they do not always make it more specific.

This article uses the term "adaptive reuse", which is already widely popular in the literature. It is used by scientists from various fields, including architects, art historians, engineers and representatives of urban studies [16,25-27]. By combining the prefix "re" with the word "use", the aspect of a new function of a building and its reintroduction into the city is highlighted.

The possible issues that can emerge when adapting architectural heritage to its new function are presented in this article from a wider perspective, as an important component in the process of reconstruction of social identity, regeneration of urban tissue and improvement in quality of life, as well as building a positive image of a city. The methodology was based on the juxtaposition of theoretical research with the critical analysis of selected projects, as case studies. Important research material included conservation concepts (primarily changes in the understanding of the social meaning of heritage) and source documents (historical documents as well as official records of Łódź authorities). The historical-interpretive method combined with the case study enabled a comprehensive analysis of the ongoing processes and their conditions. Thanks to the research on international documents devoted to the protection of the architectural heritage, the observed phenomena were placed in a broader context. The main aim of this article is to contribute to a new theoretical understating of the role and importance that adaptive reuse can play in a modern city and its reconstruction after a disaster. The adaptive reuse is seen not only as an opportunity to preserve individual objects characteristic of the urban landscape, but also as an important element of sustainable development, in terms of ecology, economy and socio-cultural aspects.

\section{The History of Łódź and the Beginnings of the City's Identity}

In the history of Łódź, three fundamental events can be identified as turning points. The first was without a doubt of a positive nature, and took place in 1820, when Łódź was declared a "factory city" by decree of the government of the Kingdom of Poland. This decision influenced the modern history of the city, which in just a few dozen years was transformed from a small settlement into a powerful, vibrant metropolis [28]. The pace of this development is well evidenced by data showing a rapid increase in the number of inhabitants. In 1821, only 799 people lived in Łódź, while in 1900 the 
population reached almost 300,000 and Łódź became the second-largest city in the Kingdom of Poland [29]. By the end of the 19th century, Łódź had become one of the largest industrial centres in Europe and the textile factories built in the city, such as the ones belonging to Karol Scheibler, could compete in terms of size with the most powerful factories in the world [30].

The industrial nature of the city determined its architectural and spatial structure. In 1920, the layout of characteristic narrow and long plots of land was created, which has influenced the urban and spatial character of Łódź ever since. However, due to the development of the most characteristic architectural buildings in the city, the period starting from the 1870s to the outbreak of the First World War was particularly important. At that time, thanks to a favourable economic situation, most of the buildings that determine the city's appearance to this day were built. Large-scale industrial complexes were constructed during that period, as well as numerous public utility buildings, mansions and tenement houses, mainly in the then-dominant historicist styles, and a little later also in the increasingly popular Art Nouveau style.

The terms "Polish Manchester" or "a country by itself", which were used in the press and literature of the late 19th and early 20th centuries when referring to Łódź, described its strictly industrial and at the same time special character very well [31] (Figure 1a). The multicultural and multinational population of the city was also gaining attention. The very special atmosphere and climate of the city was described by the Nobel Prize winner Władysław Reymont in his novel Ziemia obiecana. The writer was fascinated by the city's wealth, its thriving businesses, all expanding at a pace that was truly American, as well as the psychology of the growing population. As he noticed, there was an ongoing and exciting process of intermingling, integration and, eventually, transformation into what was referred to as lodzermensch [32] (Figure 1b).

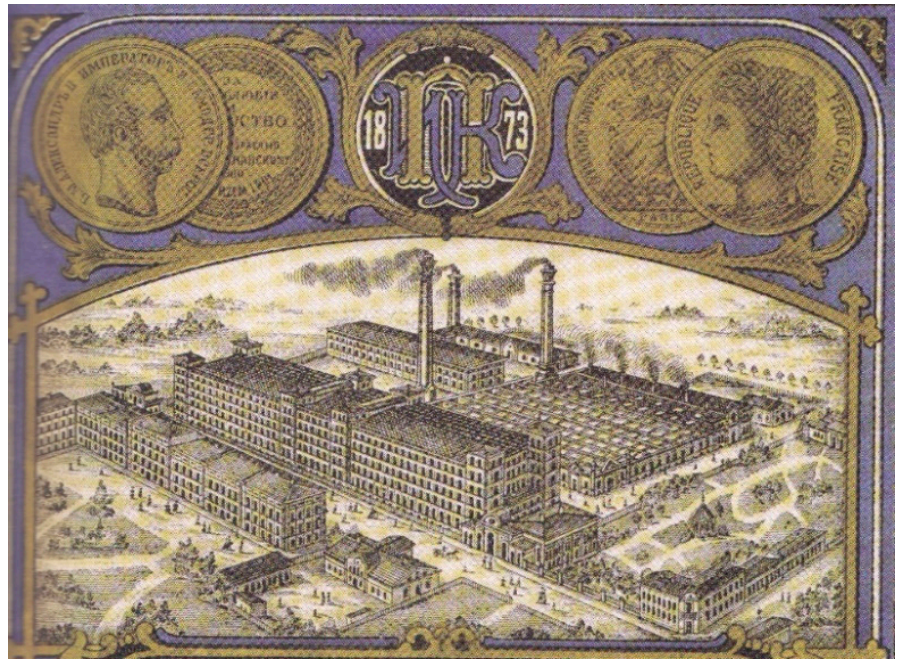

(a)

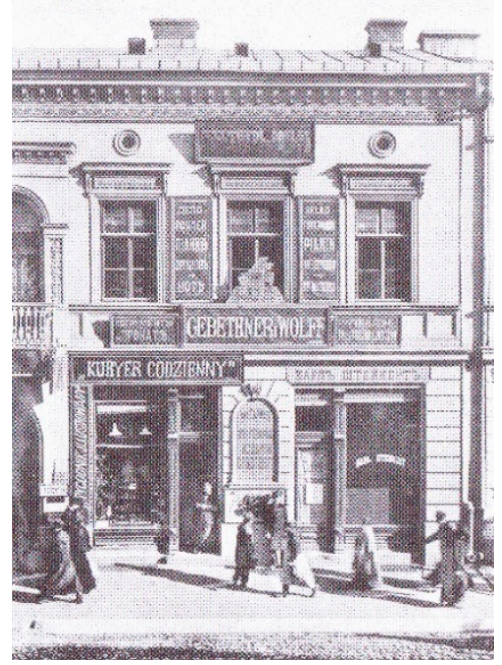

(b)

Figure 1. 19th-century industrial and multicultural Łódź: (a) Factory label of Izrael Poznański's company, 1840 [33]; (b) Gebethner and Wolff's Piano Warehouse. Signs in Polish, German and Russian on the facade, 1896 [34].

An important milestone in the history of Łódź was the Second World War and, at its end, the introduction of communism. During the war, the architectural tissue of the city was not significantly damaged, so it did not require any major alterations [35]. Although in the post-war Polish People's Republic the factories were nationalised, the textile industry remained to serve as a foundation for the city's economic development, and Łódź was still being referred to as the city of "one hundred factories" and "one hundred chimneys" [36]. A significant change, however, took place in the ideological and propaganda arenas. In the early post-war years, the capitalist past of Łódź was heavily and radically criticised, and the historical role and contribution of former factory owner families in the 
city's development were reinterpreted. The Łódź of factory owners was transformed into a city of the working class. The construction of a completely new reality began, based on the contrast between "bad" and "good" times_the hostile capitalist past and the glory of the socialist future [37]. In order to make the communist rule credible and to establish the "new face of the city" [38], "the red Łódź" and "the avant-garde of the Polish proletariat" [39], the authorities were creating narratives based on a selective interpretation of the city's history, emphasising pre-war revolutionary traditions [38].

The city's multicultural past was being systematically erased. As a result of the war, as well as the subsequent post-war communist policy, the structure of the city's population was transformed. The abrupt end of the multicultural and multinational history of Łódź is demonstrated by both the Nazi's extermination of the city's Jewish community and the post-war forced displacement of the German population [40]. After the Second World War, it is safe to describe the city's population as monocultural, while in the 1890s, over 40\% were Germans, about 30\% Poles and slightly more than $20 \%$ Jews, with Russians constituting less than 1\% of the population [29]. The community which formed a multicultural, architecturally diverse pre-war Łódź was destroyed, a community that was emotionally connected with the city and could play an important role in maintaining its integrity as well as its historical continuity.

However, the event that most significantly affected the city's foundations, and their material, social, and economic aspects - an event that led to degradation of the city's architectural tissue-was the collapse of industry caused by the political transformation of 1989. It is a peculiar paradox: a positive change in the political sense meant a tragedy for the city, its economic life and its architectural heritage - a catastrophe more devastating than the Second World War.

\section{Disaster and Post-Disaster Recovery}

As a result of the political transformation that began in Poland in 1989, Łódź found itself under the influences of overlapping and intensive processes typical of a post-socialist as well as a post-industrial city. The interruption in continuity of the economic system as well as a change in the system of values, and consequently in the most basic aspects of social existence, led to profound political, social, economic and spatial transformations [41]. Łódź experienced a sudden collapse of the textile industry, which up to that point had served as a foundation for the city's economy; and, as a consequence, a deep economic, social, and demographic crisis. Thus, after over 170 years, the industrial era of Łódź came to an end in an extremely violent manner.

The liquidation of the city's numerous factories threatened the existence of characteristic buildings and entire industrial complexes, inextricably linked to the urban landscape. Huge 19th-century factory buildings, which were difficult to maintain, started to degrade (Figure 2a,b). Abandoned buildings became a characteristic element of the urban landscape of Łódź in the 1990s. This problem primarily affected the very centre of the city, where the mixture of residential and factory functions was most common (today, the area features 200 factory buildings, 27 palaces and 47 factory owners' villas, and about 3800 tenement houses). In 1996 alone, several million square metres of space in factory halls were put up for rent in Łódź. According to Bartosz M. Walczak, this could be compared to what was offered for rent in the whole of Northern England ten years earlier [42].

While in the 19th century Łódź developed extremely rapidly, in the 1990s, after the transition to a market economy and due to the closure of large industrial estates, the city was in an almost equally rapid and severe recession. As a consequence of the political transformations and the need to survive in the new reality, it became necessary to reinvent not only the economic foundation of the city, but also to create a clear and positive image of Łódź, which would bring both social and economic benefits [43,44].

The political changes stimulated a form of urban self-reflection and served as a catalyst to look closer at the history of the city. It was never (especially at the beginning of the transformation period) a head-on critical type of reflection, but rather a search for positive values that could contribute to the consolidation of the local community and the creation of a contemporary, coherent image of the city. The main efforts focused on rehabilitating the industrial legacy of the city. This encouraged the 
emergence of narratives promoting the multicultural, ethnically diversified heritage of Łódź $[45,46]$. These aspects of the past are referred to by the city's authorities during various campaigns, conferences, events and discussions $[47,48]$. The city's past became a crucial point of reference, a source of inspiration, but also a source of hope for the future. The memories from the period of the city's rapid industrial development-when, as described by the 19th-century author Oskar Flatt, "there was first poverty, then a spark of life, [...] prosperity emerged, and after a few questionable steps Łódź was at the top" [49]-become important. Such remembrances could also give hope to overcoming the crisis of the 1990s, a chance of rebirth in the city struggling with progressive closures of factories and increasing unemployment.

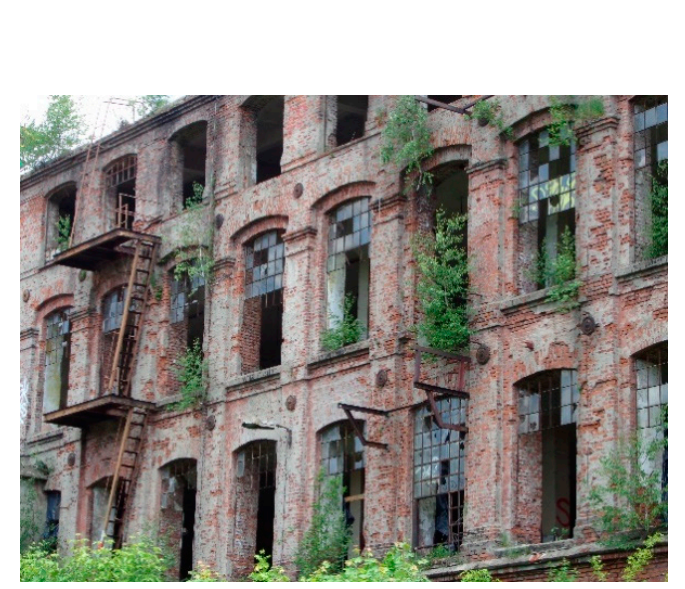

(a)

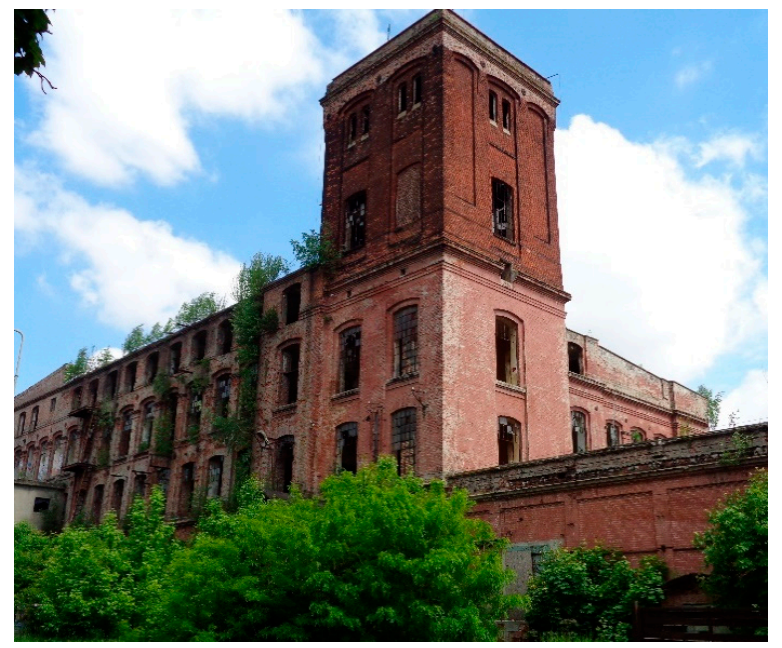

(b)

Figure 2. Degradation of the factory complex as a result of production liquidation in the 1990s. (a,b) The facilities formerly belonging to Karol Scheibler and Ludwik Grohman's United Cotton Industry Plants (author: Julia Sowińska-Heim).

In the 1990s, at the beginning of the transformation period, the need to revive the city's 19th-century architectural heritage had already been recognised as an important element of cultural identity, promoting the integration of citizens and their identification with the city [50]. The pro-social and pro-urban attitudes, supported by an emphasis on the historical values of buildings, were aimed at breaking the stereotypical perception of Łódź as an unattractive, neglected working-class city, which has been established during the communist period (this process is still ongoing). In the documents prepared at the request of the city's authorities, there is a noticeable tendency to assign a double role to the 19th-century architecture of Łódź. On the one hand, it is being approached as an important element in creating the identity of the city (which is used to build up its competitive brand name), and on the other hand, the architecture should help create an emotional bond with the city and among its inhabitants (social aspect) $[45,46,51]$.

Initially, a major effort was made to revitalise Piotrkowska Street. This characteristic artery, $4 \mathrm{~km}$ long, has been recognised as a landmark of the city since the beginning of the industrial period (Figure 3). Piotrkowska was famous for its commercial, social and cultural life. It is worth noting that one hundred years later, in the 1990s (that, is in the beginning of the transformation period), nearly $50 \%$ of the industrial areas located in Piotrkowska Street changed their function [52]. Significantly, in an official document issued by the City Council in 2004, it was stressed that the collapse of industry and the consequent switch from production to services (commercial, cultural, business or banking) created a unique opportunity to reorganise the city centre and give it a metropolitan character, for the first time in the two-hundred-year history of Łódź [53]. Although the idea was born at a time when the city was 
in a dire situation, including the ongoing deterioration of its architectural tissue, these circumstances were recognised as a turning point, which paradoxically became an opportunity for Łódź.

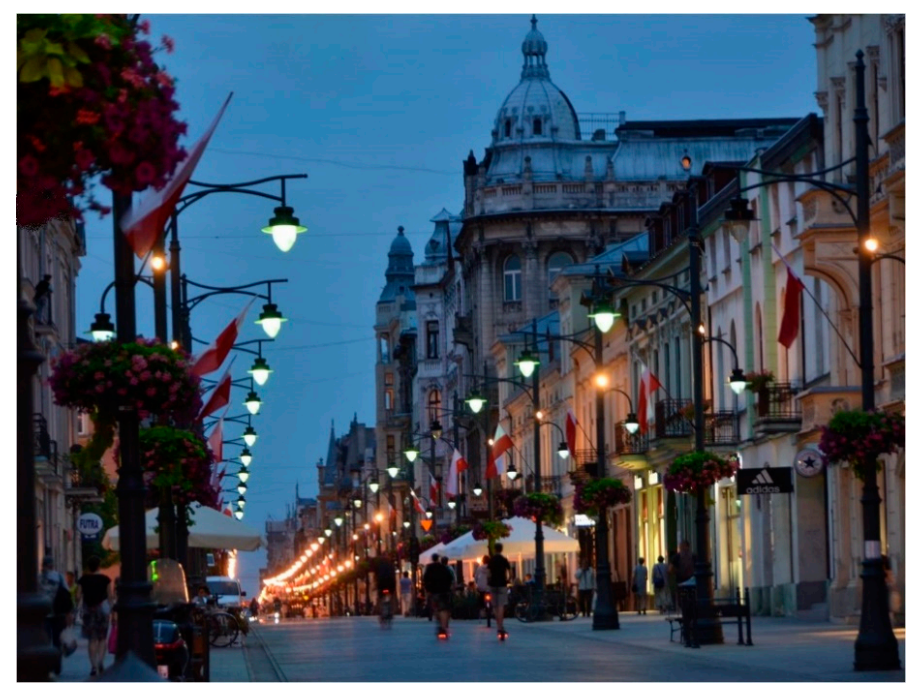

Figure 3. Piotrkowska Street—-the main urban, historical and symbolic axis of Łódź. It is worth noting the repaving and installation of replicas of historic street lighting (author: Julia Sowińska-Heim).

The change in attitude towards the city's past became noticeable, as well as the attempts to create a bridge between the past and the present in the form of large-scale adaptive reuse of post-industrial architecture. After the first period of transformations taking place in Łódź in the 1990s, at the beginning of the 21st century, a large-scale process of adaptive reuse of post-industrial buildings and complexes began. This was when many award-winning projects were created in Łódź, such as Manufaktura (referred to as the "largest shopping centre in Eastern Europe" [54]) or the lofts "U Scheiblera" (modern apartments set up in a former huge four-storey spinning mill) (Figure 4). As a result, a fragmentary revitalisation was carried out in the areas once belonging to the two largest industrial tycoons of the 19th century in Łódź-Izrael Poznański and Karol Scheibler [55]. The projects associated with introducing new functions took various forms, ranging from macro-scale projects (such as municipal investments in the revitalisation of the former EC1 power plant complex as part of the New Centre of Łódź (Figure 5b) or the vast areas of Księży Młyn) to micro-scale projects located in different parts of the city. Among numerous projects, it is worth mentioning OFF Piotrkowska, which gives the impression of a spontaneous and uncontrolled adaptive reuse of the architectural heritage, or Art Inkubator (Figure 5a). All these fit well within the concept of urban regeneration adopted in 2011 under the common theme of creative activities and cultural industry [51]. All of these undertakings have taken place in post-industrial areas. 


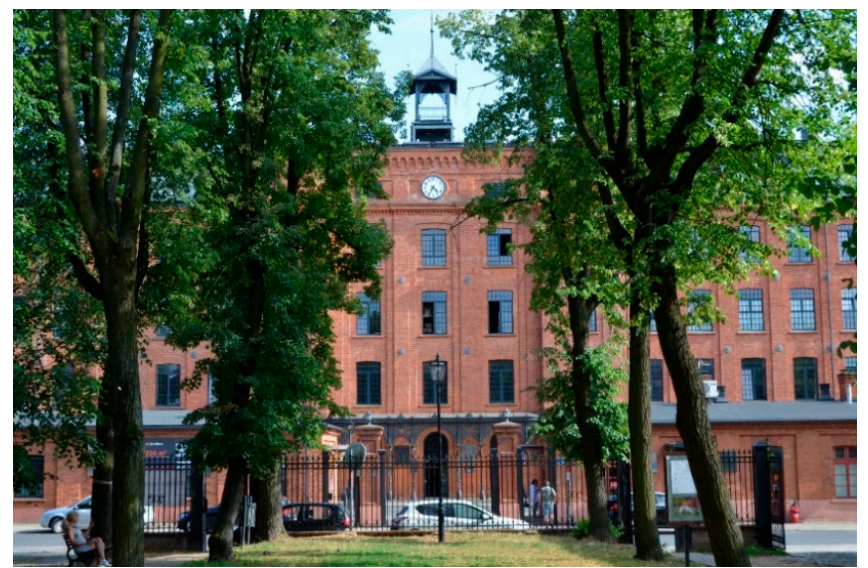

Figure 4. Lofts in Karol Scheibler's 19th-centry monumental spinning mill (author: Julia Sowińska-Heim).

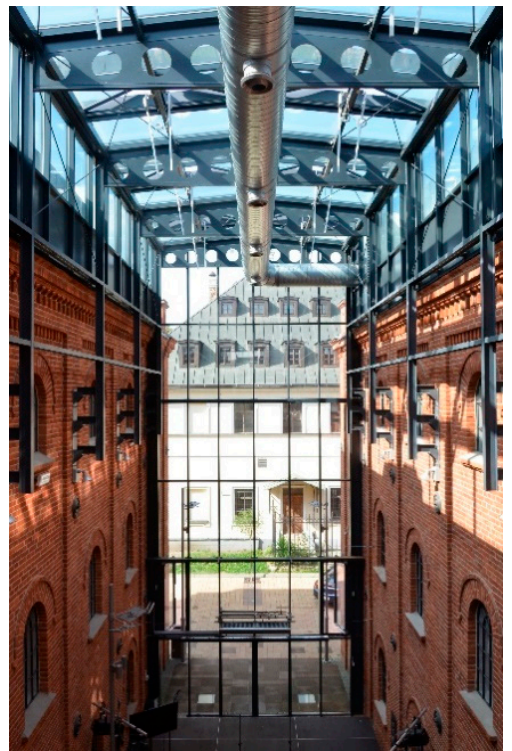

(a)

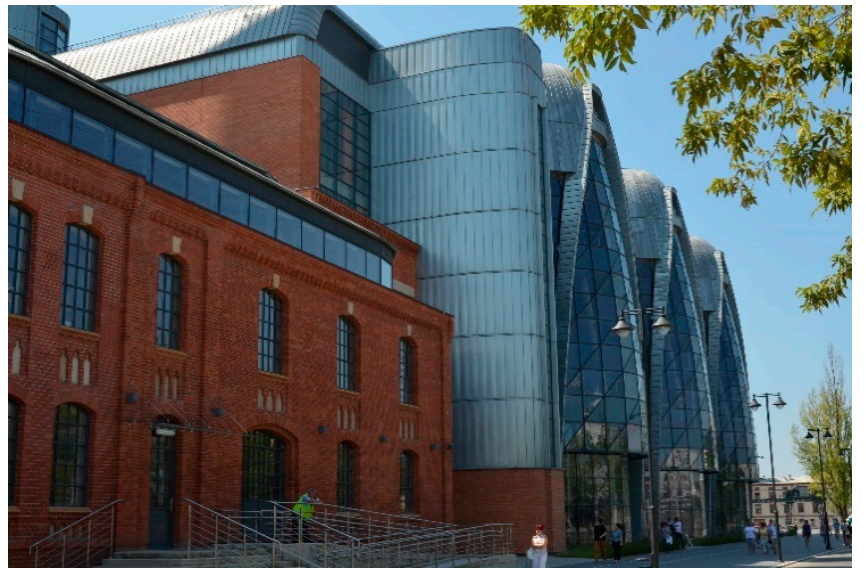

(b)

Figure 5. Examples of adaptation of post-industrial buildings in Łódź for cultural and educational functions: (a) Art_Incubator, former 19th-century factory buildings belonging to Karol Scheibler and Ludwik Grohman's United Cotton Industry Plants; (b) Planetarium in renovated buildings of the former EC1 power plant (author: Julia Sowińska-Heim).

\section{Transformations and Redefinitions of the Architectural Heritage}

Among many historical buildings and architectural complexes that have undergone a functional change and are important from the perspective of the city's identity, two projects are particularly interesting: Manufaktura and Off Piotrkowska. Both the public and the city's authorities recognised them as exemplary, although these are not municipal projects, as they were carried out by private investors [56]. A brief and very general analysis of the reasons for the social success of the two projects indicated, among others, a conscious and consistent planning of the function and aesthetics of the area, i.e., clear guiding thoughts or leading themes that allow for organising the urban space and the easy identification of individual areas located within the city centre. Off Piotrkowska was also identified as being important to stimulate "a bold dialogue between what's contemporary and the heritage" [56] (p. 68). This comparison becomes more interesting when taking into consideration the fact that the methods of shaping both areas of the city's architectural heritage were based on different concepts, 
ideas and aesthetics. Furthermore, Off Piotrkowska was intended as a counterpoint to the already completed Manufaktura.

\subsection{Case Study 1: Manufaktura. Commercial Functions and Identity of the Place}

The most spectacular effect of the reconstruction after the disastrous collapse of industry, having true significance for Łódź and its inhabitants, was the revitalisation and adaptive reuse of a part of the former residential and factory complex of Izrael Poznański. The factory, created in the 1870s and 1880s and gradually expanded until the outbreak of World War I, was the second largest and most powerful cotton factory in Łódź. The whole was and still is an important architectural and urban planning component of the city space. The characteristic forms of the brick gate, once leading to the factory premises, and the huge body of the five-storey spinning mill are among the most important monuments and most recognisable landmarks in Łódź.

For over a hundred years the factory has been a symbol of the power of Łódź industry. In 1991, after the political transformation, the factory was put into liquidation. Six years later, production ceased and nearly 30 hectares of the post-industrial area, located in the city centre, near Piotrkowska Street, became a functionally dead space. In 1993, the former Izrael Poznański factory was considered to be the "core of the city's special identity", and thus the "space of public good" [50]. It was then indicated that the existing buildings and the urban layout had to be preserved and that public recreational functions had to be introduced in the area. However, four years later, the Łódź City Council adopted a resolution changing the designation of the area to "general commercial and service purposes" and allowed the development of new structures, which, as indicated, should nevertheless harmonise with the historic buildings [57]. It should be remembered that in the 1990s, when decisions were made as to how to preserve this architectural complex which had such great significance for the city, Łódź experienced a deep collapse. The huge declining post-industrial buildings and the size of the entire area constituted a considerable investment challenge, requiring significant financial investment. For these reasons, functional change, although so necessary, seemed to be difficult. Moreover, in the post-socialist city, the vision of creating attractive, vibrant commercial spaces was a kind of novelty, known only from Western European cities. Although the proposal made by a French investor, Apsys, to preserve and maintain the historic architecture important for Łódź, as well as to revitalise (both economically and socially) this part of the city centre and create attractive places for the inhabitants, raised some concerns, it seemed to be the most appropriate solution at the time.

In 2006, a huge shopping and entertainment centre, Manufaktura, the largest investment of this kind in Poland at that time, was opened on the premises of the former plant. Its modernised post-industrial facilities were supplemented with new buildings. An important part of the post-industrial complex is a four-star Andel's Hotel, occupying a monumental building of the former 1876-8 spinning mill (170.4 m long $\times 30.5 \mathrm{~m}$ wide), the most characteristic for the whole complex (Figure 6a,b). The former 1895 weaving mill hosts a branch of the Museum of Art in Łódź (ms2) with one of the oldest permanent collections of modern art in Europe. 


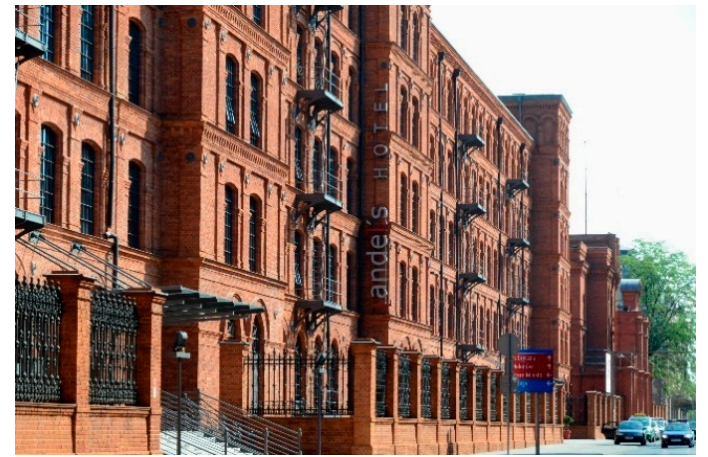

(a)

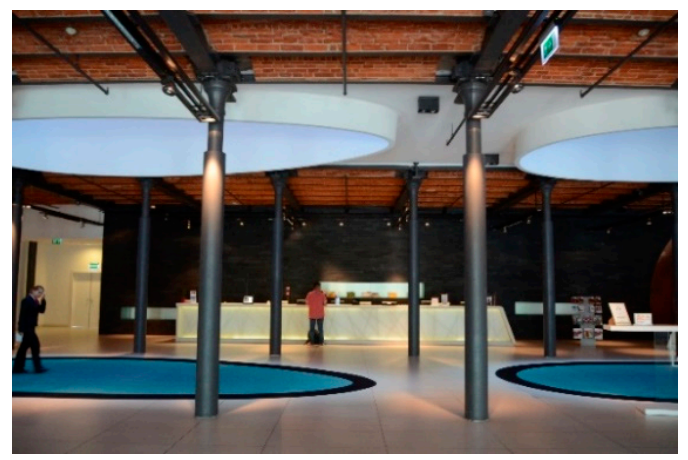

(b)

Figure 6. Andel's Hotel in the former 19th-century Izrael Poznański spinning mill: (a) Façade; (b) Interior-reception desk (author: Julia Sowińska-Heim).

In total, about $90,000 \mathrm{~m}^{2}$ have been adapted to the new function, which allowed for the preservation of the red brick buildings characteristic of Łódź. New structures, with an area similar to that of the historical buildings $\left(95,000 \mathrm{~m}^{2}\right)$ were discreetly inserted into the existing architectural and urban layout. The old and new buildings together form a well thought-out and harmonious spatial composition, and the character of the place is determined by 19th-century factory architecture. The transformations resulted in the creation of a visually coherent architectural complex, which, thanks to the specific aesthetics of historical architecture, has a unique character. Demolitions performed within the complex led to establishment of a centrally located "market" with an area of 30,000 $\mathrm{m}^{2}$, being an attractive space, extremely popular among inhabitants and visitors (Figure 7). However, the creation of the market led to an irretrievable loss of the specificity of the place, associated with the influence of the layout of narrow internal streets and characteristic passages between brick buildings.

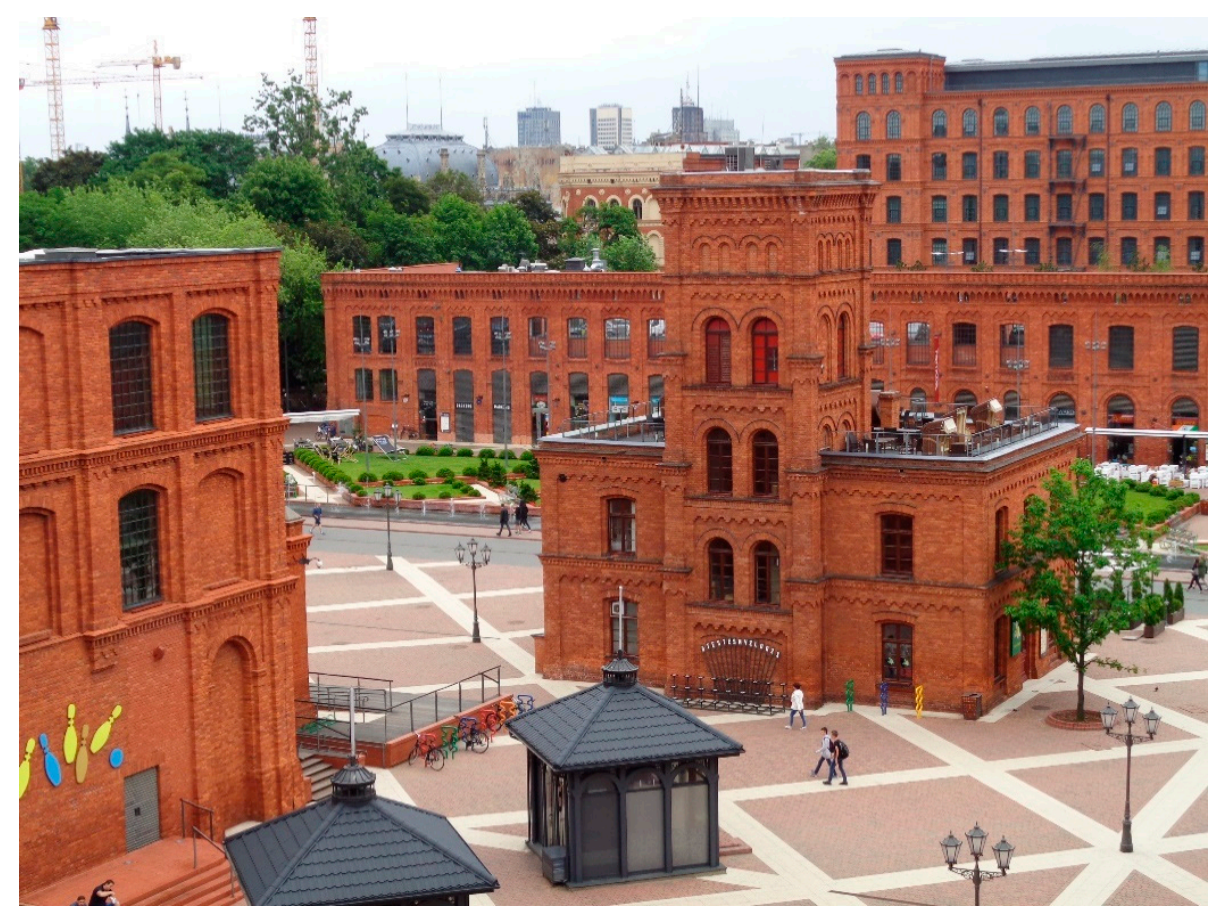

Figure 7. Izrael Poznanski's former industrial complex adapted to the new function and the market of Manufaktura (author: Julia Sowińska-Heim). 
In the case of Manufaktura, there has been a tendency, characteristic of contemporary theme centres, to bring a sense of authenticity while carefully controlling the image being built [58]. In order to obtain an interesting, attractive form for inhabitants and visitors, the space was subjected to a thoughtful process of spectacularisation [59-61], giving it a hybrid character. A kind of "facadisation pandemic", which has overwhelmed both Europe and the United States and represents a significant challenge for the protection of the architectural heritage [62], was not avoided in this case either. In the course of the functional change, the main emphasis was placed on the preservation of the external form of 19th-century structures, with significant interference and changes to the interiors. The buildings forming a part of the former Izrael Poznanski's factory have become attractive scenery, and only the facades, belonging to the public zone, manifest a connection with the past. The interiors of the Andel's Hotel have been treated differently: an unexpected connection between tradition and modernity became the key to its design concept (Figure 6b).

Building the image of the place based on references to local architectural identity and a synergy of tradition and modernity led the consumers to regard the place as the city's showcase. The use of existing buildings, which are an integral part of the urban landscape, makes the new commercial centre credible and legitimate. Emphasising the historical continuity of form creates an impression of credibility and honesty [63]. At the same time, however, a disturbing phenomenon may occur, in which cultural meanings become primarily a commercial artefact-although, as Sharon Zukin pessimistically states, it is nowadays shopping that has become a deeply cultural experience $[64,65]$. Historical walls are then more of a visual sign than a document of the past and a point of reference that can play a permanent role in building urban identity.

In the case of the adaptive reuse of large post-industrial complexes, preserving the integrity of the place is also a significant problem. New divisions resulting from the introduction of diverse functions into once carefully thought-out architectural and urban complexes may also blur the original concept and ideological expression of the complex. As a result of modernising a fragment of the former Izrael Poznański's complex and turning it to a shopping centre, new divisions modified the previous composition within the complex. First of all, Ogrodowa Street, once the main internal axis, became the border, while the artificially created Manufaktura market became the central axis.

The transformations connected with the adaptive reuse of post-industrial buildings forced the city's authorities to take action in the neighbouring areas, relating to, among others, the renovation, modernisation and adaptive reuse of the former workers' houses. The official rhetoric concerning the commencement of the work and the direction of the adaptive reuse (the residential function is to be replaced by the service function) links the importance of the place and the value of the complex with the commercial success of the shopping centre, without paying much attention to the historical, cultural and social significance of this unique architectural heritage [66]. It has also become an important challenge to develop solutions that would foster a harmonious coexistence of the shopping and entertainment complex with the historical, urban structure and would allow for the restoration of the desired cohesion of the central space of the city [53].

Manufaktura is considered to be the "icon" of industrial Łódź and, at the same time, a symbol of its post-industrial revival. Although the shopping centre is promoted as the contemporary driving force of Łódź, aspiring to the role played by Izrael Poznański's factory in the 19th century, it does not directly contribute to the development of other urban areas [41]. The shopping, service and entertainment centre has taken on the function of a new urban forum, attracting crowds of inhabitants and tourists, and thus depriving the historical centre of Łódź, namely Piotrkowska Street, of its role as the primary meeting place [67] (Figure 8). On the other hand, the reinterpretation of heritage through the prism of contemporary needs and trends created a space attractive to a contemporary user, and, although its character is far from the original, it fits well with the social need to create an orderly, aesthetically coherent "public" space in Łódź. 


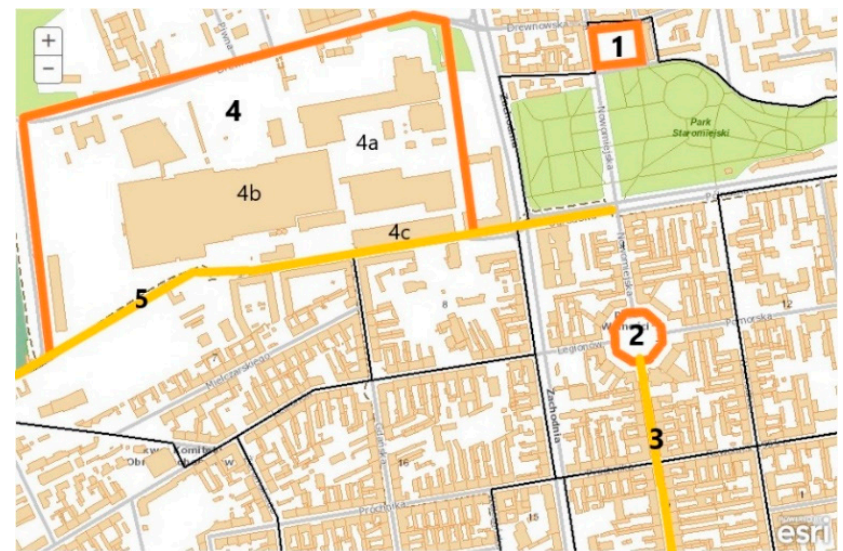

(a)

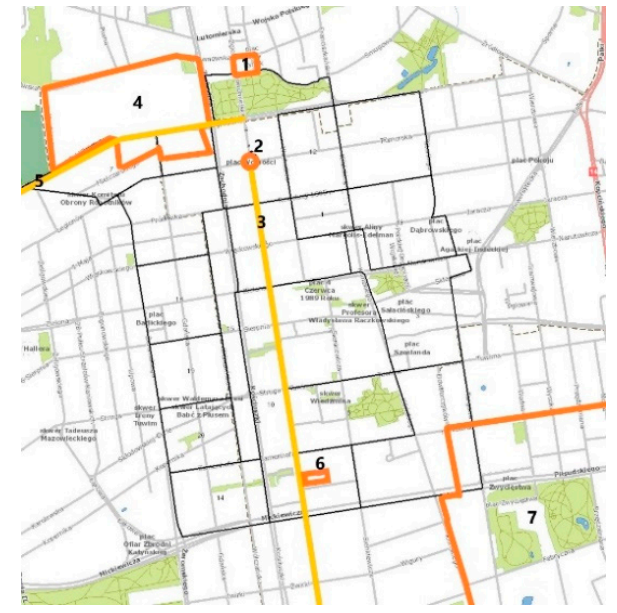

(b)

Figure 8. A fragment of the centre of Łódź: (a) 1. The Old Town Square; 2. The New Town Square-the main square of the city created in the 19th century (currently Wolności Square); 3. Part of Piotrkowska Street; 4. Izrael Poznański's factory complex-currently Manufaktura; 4a. Market of Manufaktura; 4b. The main building of the shopping centre-a contemporary building; 4c. Andel's Hotel in former Izrael Poznański's 19th-century spinning mill; 5 . Ogrodowa Street; (b) 1. The Old Town Square; 2 . The New Town Square; 3. A fragment of Piotrkowska Street; 4 . The outline of Izrael Poznański's factory complex; 5. Ogrodowa Street; 6. Franciszek Ramisch's 19th-century factory, currently Off Piotrkowska 7. A fragment of the former factory and residence complex of Karol Scheibler.

\subsection{Case Study 2: Off Piotrkowska. Functions Related to Creative Activities}

Based on the analysis of Łódź's potential performed in 2011, the city's authorities decided that the concept of the creative city consolidated and properly directed activities aimed at building a clear image and brand of the city in the post-socialist and post-industrial reality [51]. Having adopted the concept, the city aligned with pan-European trends, at the same time referring to the local architectural and cultural heritage (film, design, photography, fashion) and avant-garde artistic activities. Thus, 19th century industrial architecture, as well as subsequent activities, institutions and artistic initiatives of international range (such as, among others, one of the first international collections of modern art in the world created in the interwar period, or subsequent activities of the internationally renowned National Higher School of Film, Television and Theatre, artistic events, such as Construction in Process, or contemporary festivals, such as Łódź Design Festival) became the main source of inspiration for contemporary Łódź.

In the official discourse, the main pillars of the city's construction are, above all, creative and entrepreneurial inhabitants and modern enterprises [45]. The creative industry is perceived in it as a cultural stimulus, and culture, in turn, as an important factor positively influencing the economic development of the city and its social perception. The adopted assumptions correspond to an approach in which functions related to culture and creative industry are treated as an important substitute for the lost industrial function and an important stimulus for creating a new, attractive image of the city [68], as well as for the reconstruction of the urban identity. Post-industrial buildings are treated primarily as an interesting and original area in which to exhibit design, photography, fashion or strictly artistic activities. The Brand Strategy and Promotion for the City of Łódź for 2010-2016 includes a statement that, through an unusual context and unexpected correlations of post-industrial architecture, adds "clarity" to the actions undertaken [51].

The basic idea of building links between the regeneration of the urban tissue and creativity, and the activation of the local community, is based on the non-standard message that although Łódź is not a beautiful city, thanks to its history, multicultural heritage and post-industrial architecture it stimulates creativity and provides favourable conditions for the development of creative, talented people, who are 
passionate about putting their ideas into practice [69]. The specific atmosphere and aesthetics of post-industrial architecture generate creative energy, while creative and unconventional activities make the city special and change it for the better. Parallel comparisons are made with reference to the city's 19th-century past, when "the contact between machine and man, [and] the accompanying continuous process of production prompted people to create something extraordinary, different, contesting the existing canons and rules" [70].

The ideas related to the regeneration and social and economic revival of the post-industrial complex through the introduction of functions related to the creative industry in Łódź were implemented in the most consistent way in the OFF Piotrkowska project, concerning the adaptive reuse of Franciszek Ramisch's 19th-century cotton weaving and spinning mill (the area is located in Piotrkowska Street, in the historical city centre). The project of adaptive reuse officially began in 2011 and, not by chance, coincided with the idea of promoting Łódź as a creative city and its main motto: "Culture in Łódź has an OFF character!", announced at that time by the city's authorities [51].

In the first visual reception, OFF Piotrkowska is a counterpoint for the post-industrial complexes which, due to the adaptive reuse, have undergone a detailed planned modernisation and far-reaching aestheticisation and spectacularisation, as was the case with Manufaktura. It gives an impression of freedom of action, including the spontaneous, bottom-up initiative of adaptive reuse. OFF Piotrkowska seems to be well suited to the needs of the creative group, searching for places open to diversity, and gives citizens the opportunity to express themselves and confirm their identity, as mentioned by Richard Florida [71]. In this case, an important role is also played by the "age value" [72], visible primarily in the area of aesthetics, a kind of patina or "surface corrosion". However, it is not about showing the historical origin of the place but about confirming its authenticity and depicting the creative synergy of the city's past and present. Therefore, it has a significant emotional value (Figure 9).
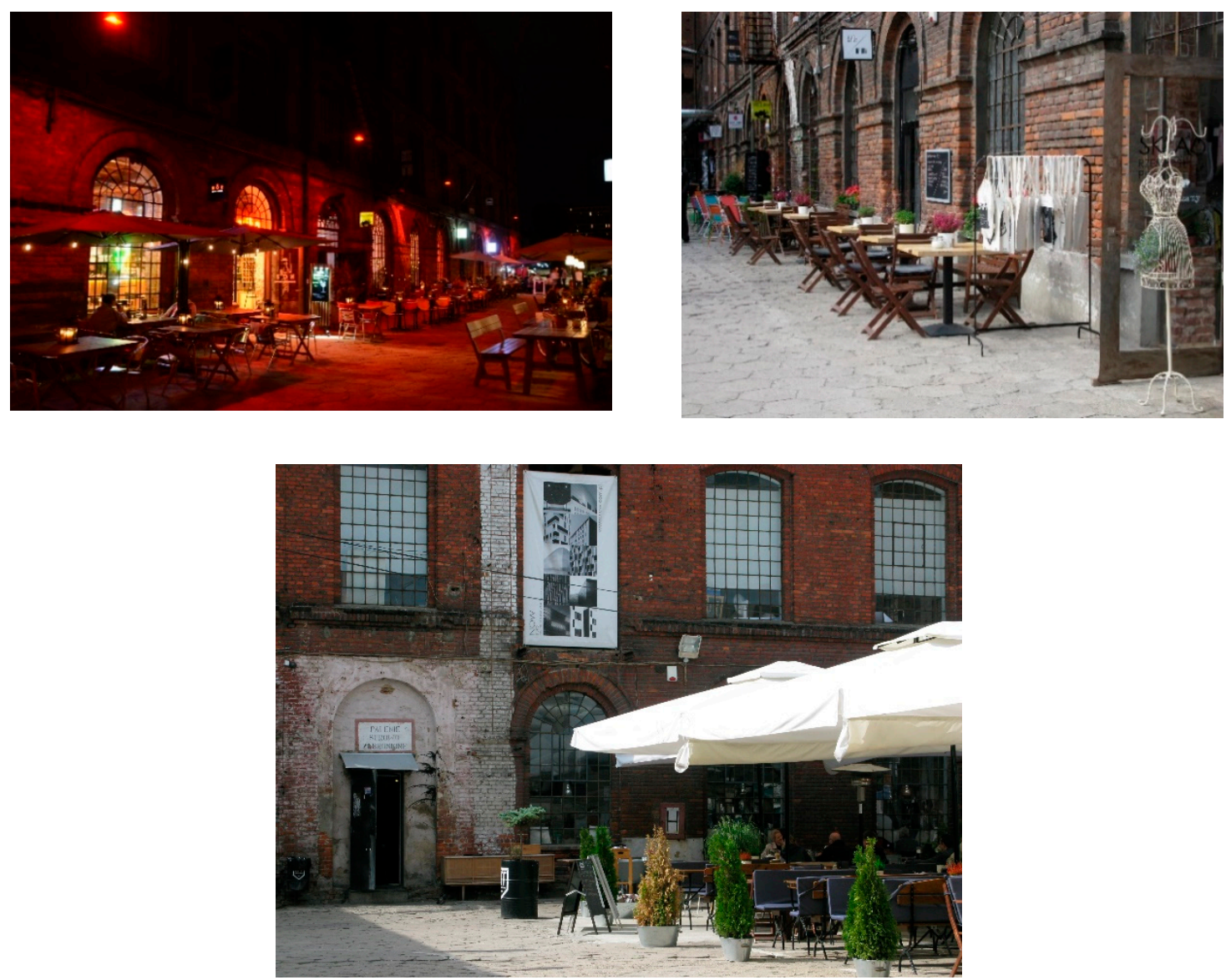

Figure 9. Off Piotrkowska in the former Ramisch factory (author: Julia Sowińska-Heim). 
When buying the premises in 2008, the developer (OPG Orange Property Group) initially had completely different plans [73]. A hotel and a retail and office complex were to be built on the site of the former factory. The concept created at that time was closer to such projects as Manufaktura. However, the economic downturn caused such a large investment to be abandoned. The post-industrial buildings were made available for various cultural activities, such as concerts, exhibitions, workshops and discussion meetings. At that time, the main event organiser was the Fabrykancka Association, an independent organisation from Łódź, which created a place for artistic activities-the so-called FabrySTREFA, in the former Ramisch factory. In 2012, the Association left the site, but at that time it had already aroused positive connotations, attracting many positively oriented tenants and users.

Charles Landry and Masayuki Sasaki particularly emphasise the idea of creativity related to art and culture as a vehicle for urban regeneration and a method for solving and reducing social problems, among other things by involving and activating local communities [74,75]. In the case of OFF Piotrkowska, however, this activation had a special significance. The informal and spontaneous nature of adaptive reuse became an impulse and inspiration for the developer in revitalising the place and carrying out further, already-planned actions on a continuous basis, without establishing clear boundaries between the subsequent stages of the undertaking [19].

A situation in which bottom-up and informal initiatives related to the revitalisation of facilities and larger, functionally dead urban areas lead to a change in the perception of the (social, architectural, historical, urban or economic) value of a place is not new. An interesting example is the Berlin-based Kunsthaus Tacheles, created by artists to be an informal art centre in an old, partially ruined shopping arcade from the early 20th century. However, the transformations and interventions carried out there did not follow a pre-determined plan or an established, prospective goal, but were temporary, perishable interventions resulting from current needs and artistic undertakings [76,77]. As time went by, the place became a well-known and important centre of alternative culture in Berlin and its social and cultural perception changed. Then, however, the phase of informal activities dramatically ended and Fundus Group, the development company, started to implement completely new plans for modernisation and adaptive reuse.

The inclusion of bottom-up activities and initiatives in the process of functional change of a building or architectural complex is of great social importance. Through direct involvement in the creation of the contemporary history of the place, the links between the local community and the site are strengthened, more than in the case of a top-down project imposed by the investor (either a developer or the city's authorities). To a certain extent, this approach also allows for a better recognition of the needs of the local community in connection with the adaptive reuse of particular buildings as well as the understanding of intangible assets perceived by the community as important and worth protecting [19].

However, there is a danger that in this case social involvement and cooperation between an investor and the local community will appear to be temporary and turn over time into a mainly commercial venture.

\section{Discussion}

Following socio-economic disaster, the adaptive reuse of the architectural heritage plays an important role in the regeneration of both the physical and social tissue of a city. In a post-industrial and post-socialist city, such as Łódź, experiencing large-scale and fast-pace changes leading to the decline of existing forms of economic and social functioning of the city, as well as the degradation of the architectural heritage, adaptive reuse has become an indispensable component of activities enabling the reconstruction and strengthening of the urban identity. The preservation of continuity, resulting from a sensitive and full understanding of the nature of the place where the new function was introduced, as noted in the Nizhny Tagil Charter, can even ensure psychological stability to the communities that have experienced a sudden interruption of their existing sources and forms of work [78] (pt. 5.V; pt. 4.III.). It is worth emphasising that, at the time when the postulates contained in 
the Charter were formulated, Łódź had been facing the challenges of rebuilding the city for over a decade, and work on the functional change of the former Izrael Poznański's factory was far advanced.

Processes related to the adaptive reuse of architectural heritage may be seen as being in line with contemporary trends, including the principles of sustainable development $[79,80]$, and the creation of cities friendly to inhabitants and the environment, where the reuse of previously developed areas is also important.

Apart from restoring socio-cultural significance, a desirable phenomenon following the adaptive reuse of architectural heritage is also the economic revival of the area. The scope of protection of the architectural heritage has been extended and is not limited to objects of "outstanding universal historical, artistic or scientific value" [81] (art. 1) or of a significant age, but also covers buildings and architectural complexes of local cultural and social importance. Therefore, the exclusion of all protected architectural buildings and complexes from ongoing city life would cause a kind of "museumization" of large urban areas. The adaptive reuse of the architectural heritage fits well with the assumptions of revitalisation, combining the postulate of taking care of the heritage and its protection with the use of existing architectural resources and adapting them to current social, marketing and economic needs.

In the case of large post-industrial areas located in downtown areas, adaptive reuse also provides a valuable opportunity to include previously closed and inaccessible areas in the city's life. The actions undertaken, however, must be carefully considered. The clarification of the new social and economic role and cultural significance prevents the fragmentation of urban space and the violation of its historical layout as a result of adaptive reuse. Regardless of the adopted functional programme (cultural, commercial, etc.), the process of revival and adaptive reuse of large post-industrial complexes must be combined with a consistent, prospective and comprehensive reflection on the city and the processes, transformations and metamorphoses taking place in it, as well as their impact on the architectural and urban planning, but also on the social changes they initiate.

Introducing a new function into the old walls is, in many cases, the only way to save the degrading architectural heritage of the city and thus preserve its identity and architectural continuity. However, the excessive aestheticisation of the place and historical buildings, aimed primarily at meeting contemporary requirements, may lead to a loss of historical values. In the case of significant modifications of the architectural tissue and the aestheticisation of space, the former objects become more of a visual sign than a real testimony of the past and a carrier of collective memory. A clear tension arises between authenticity (of tangible and intangible values) and the introduced change. The loss of the original function alone creates new contexts and meanings. A factory that has lost its initial industrial purpose becomes a relic of the past and evokes and provokes various evaluations, gestures and attitudes towards the represented history. It may be perceived as a sign of progress and development or as a symbol of exploitation of labourers and class struggle. According to Pomian, being transferred into the semiotic cycle, it becomes a material carrier of meanings [82], an artefact open to cultural interpretation. At the same time, the introduction of a different function adapted to current needs provides it with a new, contemporary meaning.

In this context, the issues connected with the adaptive reuse of architectural heritage are also associated with the idea of sustainable development, referring first of all to its key statement about guaranteeing a development that satisfies the needs of the contemporary generation, without compromising the chances of future generations to satisfy their needs [83]. In this respect, with regard to the architectural heritage, the most important thing is to introduce changes that will be satisfactory for contemporary society and at the same time will not exclude the future understanding and perception of the artefact as a testimony of the past.

The conviction-formed in the 19th century and established in the 20th century, by modernists, among others-about the need to clearly distinguish between the "old" and the "new" led to a specific tension or even conflict between modern architectural designs and concepts and the architectural heritage existing in cities. However, since the end of the twentieth century, concepts that are closer to the traditional approach accompanying communities over the centuries have become more visible. 
Before the revolutionary changes in the approach to the past initiated at the turn of the 18th and 19th centuries, buildings from the past were preserved and maintained for as long as they were of use. This approach did not rule out giving selected monuments a special meaning, which, after Alois Riegl, can be described as "commemorative value" [70]. At the same time, the "memory" of times, events or figures from the past, as well as respect for them, did not exclude the interference with the original material substance of the monument, its modernisation or functional or aesthetic change.

\section{Conclusions}

Architectural heritage is constantly confronted with a rapidly changing world. The very idea of the city entails a unity of the past and the future [84], and the urban tissue is a metaphor for society [85] and the processes and transformations to which it is subject. The introduction of a new function into the historical structure is a special meeting of tradition and modernity, constituting an inseparable part of complex processes inscribed in the life of cities, in which the past becomes an integral-open and dynamic - part of the present.

The contemporary scale of the phenomenon and complexity of the issues concerning the adaptive reuse of architectural heritage are a consequence of the multi-faceted transformations that have taken place in recent decades in the social, cultural and economic spheres, and, consequently, the contemporary understanding of the role and significance of the architectural heritage. The dynamics of change, as well as individual (local) conditions, mean that at this stage of research there is no universal model of analysis or way of describing the whole range of phenomena related to the introduction of architectural heritage into the contemporary life of the city. The perception of diverse and complex dependencies, contexts and impacts may lead to a better understanding of the role that the adaptation of architectural heritage can play in the contemporary city and society.

Funding: This research has been supported by the special research fund of Hasselt University (R-7843).

Conflicts of Interest: The author declares no conflict of interest.

\section{References and Notes}

1. Dubos, R.J. Pochwała Różnorodności; PIW: Warszawa, Poland, 1986.

2. Council of Europe Framework Convention on the Value of Cultural Heritage for Society (Faro Convention). October 2005.

3. The Charter of Krakow 2000. Principles for Conservation and Restoration of Build Heritage, Cracow, October 2000. Available online: http://smartheritage.com/wp-content/uploads/2015/03/KRAKOV-CHARTER2000.pdf (accessed on 12 September 2020).

4. European Charter of the Architectural Heritage. Adopted by the Council of Europe. October 1975. Available online: https://www.icomos.org/en/charters-and-texts/179-articles-en-francais/ressources/chartersand-standards/170-european-charter-of-the-architectural-heritage (accessed on 12 July 2020).

5. The Declaration of Amsterdam. Congress on the European Architectural Heritage, 21-25 October 1975. Available online: https://www.icomos.org/en/and/169-the-declaration-of-amsterdam (accessed on 12 July 2020).

6. UNESCO Recommendation Concerning the Safeguarding and Contemporary Role of Historic Areas, Warsaw-Nairobi. 1976. Available online: https://www.icomos.org/publications/93towns7o.pdf (accessed on 12 July 2020).

7. The Australia ICOMOS Charter for Places of Cultural Significance (Burra Charter), Burra. 1999. Available online: https://australia.icomos.org/wp-content/uploads/BURRA_CHARTER.pdf (accessed on 12 September 2020).

8. The Australia ICOMOS Charter for Places of Cultural Significance (Burra Charter), Burra. 2013. Available online: http://portal.iphan.gov.br/uploads/ckfinder/arquivos/The-Burra-Charter-2013-Adopted31_10_2013.pdf (accessed on 12 July 2020).

9. Québec Declaration on Preservation of the Spirit of Place, Canada, October 2008. Available online: https://whc.unesco.org/uploads/activities/documents/activity-646-2.pdf (accessed on 12 September 2020). 
10. International Charter for the Conservation and Restoration of Monuments and Sites (The Venice Charter 1964). Adopted by ICOMOS in 1965. Available online: https://www.icomos.org/charters/venice_e.pdf (accessed on 12 July 2020).

11. Mason, R. Assessing values in conservation planning: methodological issues and choices. In Assessing the Values of Cultural Heritage; de la Torre, M., Ed.; Research Report; The Getty Conservation Institute: Los Angeles, CA, USA, 2002; pp. 5-30.

12. Sowinska-Heim, J. Transformacje i Redefinicje. Adaptacja Dziedzictwa Architektonicznego do Nowej Funkcji a Zachowanie Ciagłości Historycznej Miejsca; Wyd. UŁ: Łódź, Poland, 2018.

13. ICOMOS Charter-Principles for the Analysis, Conservation and Structural Restoration of Architectural Heritage, Victoria Falls. 2003. Available online: https://www.icomos.org/charters/structures_e.pdf (accessed on 12 September 2020).

14. Feilden, B.M. Conservation of Historic Buildings; Architectural Press: Oxford, UK, 2003.

15. UNESCO. UNESCO Recommendation on the Historic Urban Landscape, Paris. 2011. Available online: https://whc.unesco.org/uploads/activities/documents/activity-638--98.pdf (accessed on 12 July 2020).

16. Plevoets, B.; van Cleempoel, K. Adaptive Reuse of Built Heritage: Concepts and Cases of an Emerging Discipline; Routledge: London, UK, 2019.

17. Brooker, G.; Stone, S. Re-Readings. Interior Architecture and the Design Principles of Remodelling Existing Buildings; RIBA Enterprises: London, UK, 2004.

18. Cantacuzino, S. New Uses for Old Buildings; Architectural Press: London, UK, 1975.

19. Plevoets, B.; Sowińska-Heim, J. Community initiatives as a catalyst for regeneration of heritage sites: vernacular transformation and its influence on the formal adaptive reuse practice. Cities 2018, 78, 128-139. [CrossRef]

20. Misırlısoy, D.; Günçe, K. Adaptive reuse strategies for heritage buildings: A holistic approach. Sustain. Cities Soc. 2016, 26, 91-98. [CrossRef]

21. Convention for the Protection of the Architectural Heritage of Europe, Granada. 1985. Adopted by the Council of Europe. Available online: https://rm.coe.int/168007a087 (accessed on 12 July 2020).

22. ICOMOS Charter for the Conservation of Historic Towns and Urban Areas (Washington Charter), Toledo-Washington, October 1987. Available online: https://www.icomos.org/charters/towns_e.pdf (accessed on 12 July 2020).

23. The Valletta Principles for the Safeguarding and Management of Historic Cities, Towns and Urban Aeras. Adopted by ICOMOS, Paris, November 2011. Available online: https://www.icomos.org/Paris2011/GA2011_ CIVVIH_text_EN_FR_final_20120110.pdf (accessed on 12 July 2020).

24. ICOMOS. New Zealand Charter for Conservation of Places of Cultural Heritage Value, New Zealand. 2010. Available online: https://www.icomos.org/images/DOCUMENTS/Charters/ICOMOS_NZ_Charter_2010_ FINAL_11_Oct_2010.pdf (accessed on 12 July 2020).

25. Bullen, P.; Love, P. The rhetoric of adaptive reuse or reality of demolition: Views from the field. Cities 2010, 27, 215-224. [CrossRef]

26. Cizler, J. The role of creative and civil initiatives in transforming post-industrial landscapes: A case study of industrial heritage re-use in the Czech Republic. Archit. Civ. Eng. 2014, 12, 207-219. [CrossRef]

27. Kirbi, A.; Kent, T. The local icon: Reuse of buildings in place marketing. J. Town City Manag. 2010, 1, 80-91.

28. In 1423 king Władysław Jagiełło granted city rights to Łódź, but up to the beginning of the 19th century it functionedas a small village rather than as a city.

29. Puś, W. Zmiany Liczebności i struktury narodowościowej ludności Łodzi do Roku 1939. In Wpływ Wielonarodowego Dziedzictwa Kulturowego Łodzi Na Wspótczesne Oblicze Miasta; Koter, M., Kulesza, M., Puś, W., Pytlas, S., Eds.; Wyd. UŁ: Łódź, Poland, 2005; pp. 9-39.

30. Yarn Roduced by Karol Scheibler's Plant Was Awarded a Gold Medal at the Industrial Exhibition in Paris in 1878. National Archive in Łódź. Available online: http://www.lodz.ap.gov.pl/art,57,lodzcy-fabrykanci (accessed on 20 July 2020).

31. Numerous Studies Indicate both Similarities and Significant Differences in the History of Development of Both Cities. In the Analyses Concerning Industrial Łódź, Lyon (France) is Often Cited as a Comparative Example; See among others: Majer, A. Socjologia i przestrzeń miejsk; PWN: Warszawa, Poland.

32. The German term Lodzermensch (lodzer-łódzki, Mensch-man) emphasized the distinctiveness of the inhabitants of industrial Łódź, and showed their strong identification with the city. The German etymology of the word indicates the multinational and multicultural character of the Łódź community of that time. 
33. Kusiński, J.; Bonisławski, R.; Janik, M. Księga Fabryk Łodzi; Wyd. Jacek Kusiński: Łodź, Poland, 2009.

34. Wilkoszewski, B. Widoki Łodzi; Łódź 1896. From the collection of the Library of the Lodz University, Special Collections-Iconography.

35. This influenced, among other things, a decision to move the State authorities between 1945 and 1948 , owning to the destruction of much of Warsaw.

36. Gzamm, J. Łódź się zmienia, czyli trochę ogólnych wrażeń. Słowo Powszechne 1951, 305, 2.

37. Karpińska, E. Miasto wymazywane: Historia łódzkiego przypadku. Studia Etnol. Antropol. 2004, 8, $165-178$.

38. Beatus, B. Zbudujemy organizacje partyjną ludu łódzkiego. Przekształcimy Łódź w miasto przemysłu, kultury i dobrobytu mas pracujących. Wywiad z tow. Kozłowskim-pierwszym sekretarzem Komitetu Miejskiego Polskiej Partii Robotniczej. Głos Robot. 1946, 94, 4.

39. Resolution of the active core of the Regional Conference of the Polish Workers' Party. Głos Robot. 1946, 98, 1.

40. Kuźma, I.B.; Sadowska, J. Łódzcy Niemcy-Fragment pejzażu Ziemi obiecanej. Problemy badawcze. Etnogr. Pol. 2011, LV, 97-132.

41. Cudny, W. Model przemiany miasta postsocjalistycznego_Przkład Łodzi. Studia Miej. 2011, 4, $153-159$.

42. Walczak, B.M. Dziedzictwo przemysłowe Łodzi: Przeszłość, teraźniejszość, przyszłość. In Rewitalizacja Miast Poprzemystowych—Rola Dziedzictwa Kulturowego; Walczak, B.M., Ed.; ŁOIIB and PŁ: Łódź, Poland, 2006; pp. $37-44$.

43. Young, C.; Kaczmarek, S. Changing the perception of the post-socialist city: Place promotion and imagery in Łódź, Poland. Geogr. J. 1999, 165, 183-191. [CrossRef]

44. Michlic, J. Lodz in the post-communist era: In search of a new identity. In Post-Communist Cities: New Cultural Reorientations and Identities; Czaplicka, J., Blair, R.A, Hopkins, J., Eds.; John Hopkins University Press: Washington, DC, USA, 2008; pp. 281-304.

45. City Council in Łódź. Integrated Development Strategy for Łódź 2020+. Act No. XLIII/824/12. Łódź. 2012. Available online: https://bip.uml.lodz.pl/files/bip/public/miasto/dokumenty/BSM_strategia_ang_20131018. pdf (accessed on 29 September 2020).

46. City Council in Łódź. Łódź Spatial Development Strategy 2020+; Act No. LV/1146/13; City Council of Łódź: Łódź, Poland, 2013.

47. History Monument Łódź-Multicultural landscape of an industrial city-Thanks to the efforts of the City Hall and Łódź scientists, the City received title from the President of the Republic of Poland.

48. An Interesting Undertaking Was, among Other Things, a Campaign Aimed at Attempting to Create a Definition of Łódź's Identity and to Provoke a Public Discussion on the Subject. The Identity of Łódź (the Assumptions of the Program to Establish a Definition of Łódź's Identity). Fundacja Ulicy Piotrkowskiej, Łódź. 2005. Available online: http://piotrkowska.pl/dokumenty/201207041455200.tozsamosclodzi.pdf (accessed on 25 February 2018).

49. Flatt, O. Opis Miasta Łodzi pod Względem Historycznym, Statystycznym i Przemysłowym; Drukarnia Gazety Codziennej: Warszawa, Poland, 1853.

50. City Council in Łódź. Spatial Development Plan for Łódź; Act No. LVII/491/93; City Council of Łódź: Łódź, Poland, 1993.

51. City Council in Łódź. Brand Strategy and Promotion for the City of Łódź for 2010-2016; Act No. VIII/81/11; City Council of Łódź: Łódź, Poland, 2011.

52. Piech, M. Plansza XXVI: Przemiany przestrzenne, gałęziowe i funkcjonalne terenów przemysłowych Łodzi w latach 1938-1999. In Atlas Miasta Łodzi; Liszewski, S., Ed.; ŁTN: Łódź, Poland, 2002.

53. City Council in Łódź. The Simplified Local Programme of Revitalization of Selected Downtown and Post-Industrial Areas of Łódź for 2004-2013; Act No. XXXIV/0568/04; City Council of Łódź: Łódź, Poland, 2004.

54. Frą, M. Le Monde pisze o Łodzi: Miasto kontrastów. Gaz. Wybor. 2011, 256, 4.

55. Sowińska-Heim, J. The identity of a city. Modern conversion of Karol Scheibler's post-industrial empire in Lodz. In Proceedings of the In Advanced Research in Scientific Areas, Žilina, Slovakia, 3-7 December 2012; Mokrys, M., Lieskovsky, A., Eds.; EDIS: Žilina, Slovakia, 2012; pp. 1240-1245.

56. City Council in Łódź. Municipal Revitalisation Programme of Łódź 2018; Act No. LXXIII/1980/18; City Council of Łódź: Łódź, Poland, 2018.

57. City Council in Łódź. Changes to the Local Area Development Plan of Łódź; Act No. LXIII/623/97; City Council of Łódź: Łódź, Poland, 1997.

58. Ritzer, G. The McDonaldization of Society: An Investigation into the Changing Character of Contemporary Social Life, 8th ed.; Sage: Los Angeles, CA, USA, 2014. 
59. Davis, S.G. Spectacular Nature: Corporate Culture and the Sea World Experience; University of California Press: Berkeley, CA, USA, 1997.

60. Variations on a Theme Park: The New American City and the End of Public Space; Sorkin, M. (Ed.) Hill and Wang: New York, NY, USA, 1992.

61. Miles, S. Space for Consumption: Pleasure and Placele ssness in the Post-Industrial City; Sage: London, UK, 2010.

62. Araoz, G. Protecting heritage places under the new heritage paradigm and defining its tolerance for change. A challenge for ICOMOS. In Conservation Turn-Return to Conservation. Tolerance for Change. Limits of Change, Proceedings of the International Conferences of the ICOMOS, International Scientific Committee for the Theory and Philosophy of Conservation and Restoration, Prague, Czech Republic, 5-9 May 2009; Florence, Italy, 3-6 March 2011; Lipp, W., Stulc, J., Szmygin, B., Giometti, S., Eds.; Edizioni Polistampa: Firenze, Italy, 2012; pp. 47-52.

63. Ashworth, G. Planowanie dziedzictwa. In Miasto Historyczne. Potencjał Dziedzictwa; Broński, K., Purchla, J., Zuziak, Z.K., Eds.; MCK: Kraków, Poland, 1997; pp. 25-48.

64. Zukin, S. Point of Purchase: How Shopping Changed American Culture; Routledge: New York, NY, USA; London, UK, 2004.

65. Zukin, S. The Cultures of Cities; Blackwell: Oxford, UK, 1995.

66. Łódź City Hall. Rozpoczynamy Druki Etap Remontu Famuły Przy ul. Ogrodowej 24. Available online: https://uml.lodz.pl/aktualnosci/artykul/rozpoczynamy-drugi-etap-remontu-famuly-przy-ulogrodowej-24-id21558/2018/7/5/ (accessed on 20 July 2020).

67. Wójcik, M. Manufaktura jako miejsce integrujące w przestrzeni społecznej Łodzi. In Łódzka Metropolia. Problemy Integracji Społecznej i Przestrzennej; Suliborski, A., Przygodzki, Z., Eds.; Wyd. Biblioteka: Łódź, Poland, 2010; pp. 42-52.

68. Hall, P. Creative cities and economic development. Urban Stud. 2000, 37, 636-649. [CrossRef]

69. Promotion of Łódź as a Creative Industries Centre. Available online: https://www.youtube.com/watch?v= txWi_OughiA (accessed on 20 July 2020).

70. Łódź Brand Management Strategy for the Years 2010-2016. Available online: https://docer.pl/doc/xv1scx5 (accessed on 12 July 2020).

71. Florida, R. The Rise of the Creative Class: And How It's Transforming Work, Leisure, Community, and Every Day Life; Basic Books: New York, NY, USA, 2002.

72. Riegl, A. The modern cult of monuments: Its character and its origin. Oppos. J. Ideas Crit. Archit. 1982, 25, 21-56.

73. Provincial Heritage Monuments Protection Office in Łódź. Koncepcja Orange Property Group (dawna fabryka F. Ramischa), sygn. 799 D.N.Hist.

74. Landry, C. The creativity city index. City Cult. Soc. 2011, 2, 173-176. [CrossRef]

75. Sasaki, M. Urban regeneration through cultural creativity and social inclusion: Rethinking creative city theory through a Japanese case study. Cities 2010, 27, S3-S9. [CrossRef]

76. Sandler, D. Counterpreservation: Decrepitude and memory in post-unification Berlin. Third Text 2011, 25, 687-697. [CrossRef]

77. Jakob, D. Constructing the creative neighborhood: Hopes and limitations of creative city policies in Berlin. City Cult. Soc. 2010, 1, 193-198. [CrossRef]

78. The Nizhny Tagil Charter for the Industrial Heritage. Orginated by TICCIH, July, 2003. Available online: www.ticcih.org/wp-content/uploads/2013/04/NTagilCharter.pdf (accessed on 12 July 2020).

79. Bullen, P. Adaptive reuse and sustainability of commercial buildings. Facilities 2007, 25, 20-31. [CrossRef]

80. Vardopoulos, I. Critical sustainable development factors in the adaptive reuse of urban industrial buildings. A fuzzy DEMATEL approach. Sustain. Cities Soc. 2019, 50, 101684. [CrossRef]

81. UNESCO Convention Concerning the Protection of the World Cultural and Natural Heritage. Paris, November 1972. Available online: https://whc.unesco.org/en/conventiontext/ (accessed on 12 July 2020).

82. Pomian, K. Museum und kulturelles Erbe. In Das Historische Museum. Labor-Schaubühne-Identitätsfabrik; Korff, G., Roth, M., Eds.; Campus Verlag GmbH: Frankfurt, Germany, 1990; pp. 41-64.

83. Report of the World Commission on Environment and Development: Our Common Future. 1987. Available online: http://www.un-documents.net/our-common-future.pdf (accessed on 12 July 2020).

84. Rossi, A. The Architecture of the City; MIT Press: Cambridge, MA, USA, 1982.

85. Rykwert, J. The Seduction of Place: The City in Twenty-First Century; Weidenfeld \& Nicolson: London, UK, 2000. 
(C) 2020 by the author. Licensee MDPI, Basel, Switzerland. This article is an open access article distributed under the terms and conditions of the Creative Commons Attribution (CC BY) license (http://creativecommons.org/licenses/by/4.0/). 